\title{
Salinihabitans flavidus gen. nov., sp. nov., isolated from a marine solar saltern
}

\author{
Jung-Hoon Yoon, So-Jung Kang, Soo-Young Lee and Tae-Kwang Oh \\ Korea Research Institute of Bioscience and Biotechnology (KRIBB), PO Box 115, Yusong, \\ Taejon, Republic of Korea
}

Correspondence

Jung-Hoon Yoon

jhyoon@kribb.re.kr

\begin{abstract}
A Gram-negative, non-motile and rod-shaped bacterial strain, ISL-46 ${ }^{\top}$, belonging to the Alphaproteobacteria, was isolated from a marine solar saltern in Korea, and subjected to a polyphasic taxonomic study. Strain ISL-46 ${ }^{\top}$ grew optimally at $\mathrm{pH} 7.0-8.0$ and $30{ }^{\circ} \mathrm{C}$ and in the presence of $7 \%(\mathrm{w} / \mathrm{v}) \mathrm{NaCl}$. It contained $\mathrm{Q}-10$ as the predominant ubiquinone and $\mathrm{C}_{19: 0}$ cyclo $\omega 8 c, \mathrm{C}_{18: 1} \omega 7 c$ and 11 -methyl $\mathrm{C}_{18: 1} \omega 7 c$ as the major fatty acids. The DNA $\mathrm{G}+\mathrm{C}$ content was $63.5 \mathrm{~mol} \%$. Strain ISL $-46^{\top}$ exhibited $16 \mathrm{~S}$ rRNA gene sequence similarity values of $94.1-95.3 \%$ to members of the phylogenetically related genera Roseivivax, Salipiger, Citreicella, Yangia and Citreimonas. Strain ISL $-46^{\top}$ could be differentiated from the above-mentioned genera by differences in compositions of the major fatty acids and in some phenotypic properties. On the basis of phenotypic, chemotaxonomic and phylogenetic data, strain ISL- $46^{\top}$ is considered to represent a novel genus and species, for which the name Salinihabitans flavidus gen. nov., sp. nov. is proposed. The type strain is ISL $-46^{\top}\left(=\mathrm{KCTC} 22485^{\top}=\mathrm{CCUG}^{\top} 6758^{\top}\right)$.
\end{abstract}

In the course of screening micro-organisms from a marine solar saltern in the Yellow Sea, Korea, many novel bacterial strains have been isolated and characterized taxonomically. One of these isolates, ISL- $46^{\mathrm{T}}$, which phylogenetically is most closely related to the class Alphaproteobacteria, is the subject of this study. The aim of the present work was to determine the exact taxonomic position of strain ISL- $46^{\mathrm{T}}$ by using a polyphasic characterization that included the determination of the phenotypic and chemotaxonomic properties and a detailed phylogenetic investigation based on $16 \mathrm{~S}$ rRNA gene sequences.

Strain ISL- $46^{\mathrm{T}}$ was isolated by means of the standard dilution plating technique at $30{ }^{\circ} \mathrm{C}$ on marine agar 2216 (MA; Difco) supplemented with $8 \%(\mathrm{w} / \mathrm{v}) \mathrm{NaCl}$. The morphological, physiological and biochemical characteristics of strain ISL- $46^{\mathrm{T}}$ were investigated using routine cultivation at $30{ }^{\circ} \mathrm{C}$ on $\mathrm{MA}(5 \% \mathrm{NaCl} \mathrm{MA})$ supplemented with $5 \%(\mathrm{w} / \mathrm{v}) \mathrm{NaCl}$. The cell morphology was examined by light microscopy (Nikon E600) and transmission electron microscopy. Flagellation was determined by using a Philips CM-20 transmission electron microscope with cells from exponentially growing cultures. For this purpose, the cells were negatively stained with $1 \%(\mathrm{w} / \mathrm{v})$ phosphotungstic acid and the grids were examined after being airdried. The Gram-reaction was determined by using the bioMérieux Gram stain kit according to the manufacturer's instructions. Growth under anaerobic conditions was determined after incubation in a Forma anaerobic chamber

The GenBank/EMBL/DDBJ accession number for the $16 \mathrm{~S}$ rRNA gene sequence of strain ISL-46 ${ }^{\top}$ is FJ265707. on $5 \% \mathrm{NaCl} \mathrm{MA}$ and on $5 \% \mathrm{NaCl}$ MA supplemented with potassium nitrate $(0.1 \%$, w/v), both of which had been prepared anaerobically under nitrogen atmosphere. Growth in the absence of $\mathrm{NaCl}$ was investigated using trypticase soy broth prepared according to the formula of the Difco medium except that $\mathrm{NaCl}$ was excluded. Growth at various $\mathrm{NaCl}$ concentrations $(0.5 \%$, w/v, and $1.0-$ $20.0 \%$, w/v, at increments of $1.0 \%$ ) was investigated in marine broth 2216 (MB; Difco) or trypticase soy broth (Difco). Growth at various temperatures $(4,10,20,25,28$, $30,35,37,40$ and $45{ }^{\circ} \mathrm{C}$ ) was measured on $5 \% \mathrm{NaCl}$ MA. The $\mathrm{pH}$ range for growth was determined in $5 \% \mathrm{NaCl} \mathrm{MB}$ that was adjusted to various $\mathrm{pH}$ values $(\mathrm{pH} 4.5-9.5$, using increments of $0.5 \mathrm{pH}$ units). Catalase and oxidase activities and hydrolysis of casein, starch and Tweens 20, 40, 60 and 80 were determined as described by Cowan \& Steel (1965). Hydrolysis of hypoxanthine, tyrosine and xanthine was tested on $5 \% \mathrm{NaCl} \mathrm{MA}$ using the substrate concentrations described by Cowan \& Steel (1965). Hydrolysis of aesculin, gelatin and urea and nitrate reduction were investigated as described previously (Lányí, 1987) with the modification that artificial seawater supplemented with $5 \%(\mathrm{w} / \mathrm{v}) \mathrm{NaCl}$ was used for preparation of media. The artificial seawater contained ( $\left(^{-1}\right.$ distilled water): $23.6 \mathrm{~g} \mathrm{NaCl}, 0.64 \mathrm{~g} \mathrm{KCl}$, $4.53 \mathrm{~g} \mathrm{MgCl}_{2} \cdot 6 \mathrm{H}_{2} \mathrm{O}$, $5.94 \mathrm{~g} \quad \mathrm{MgSO}_{4} \cdot 7 \mathrm{H}_{2} \mathrm{O}$ and $1.3 \mathrm{~g}$ $\mathrm{CaCl}_{2} \cdot 2 \mathrm{H}_{2} \mathrm{O}$ (Bruns et al., 2001). $\mathrm{H}_{2} \mathrm{~S}$ production was tested as described previously (Bruns et al., 2001). Susceptibility to antibiotics was investigated on $5 \% \mathrm{NaCl}$ MA plates by using antibiotic discs with the following concentrations; polymyxin B (100 U), streptomycin $(50 \mu \mathrm{g})$, penicillin $\mathrm{G}(20 \mathrm{U})$, chloramphenicol $(100 \mu \mathrm{g})$, 
ampicillin $(10 \mu \mathrm{g})$, cephalothin $(30 \mu \mathrm{g})$, gentamicin $(30 \mu \mathrm{g})$, novobiocin $(5 \mu \mathrm{g})$, tetracycline $(30 \mu \mathrm{g})$, kanamycin $(30 \mu \mathrm{g})$, lincomycin $(15 \mu \mathrm{g})$, oleandomycin $(15 \mu \mathrm{g})$, neomycin $(30 \mu \mathrm{g})$ and carbenicillin $(100 \mu \mathrm{g})$. Utilization of various substrates for growth was determined as described by Baumann \& Baumann (1981), using supplementation with $5.8 \%(\mathrm{w} / \mathrm{v}) \mathrm{NaCl}$ and $0.01 \%(\mathrm{w} / \mathrm{v})$ yeast extract. The carbon sources were added at a concentration of $0.2 \%$ $(\mathrm{w} / \mathrm{v})$ after sterilization by filtration. Enzyme activities were determined by using the API ZYM system (bioMérieux).

Cell biomass for DNA extraction and for isoprenoid quinone analysis was obtained from cultures grown in $5 \%$
$\mathrm{NaCl} \mathrm{MB}$ at $30{ }^{\circ} \mathrm{C}$. Chromosomal DNA was isolated and purified according to the method described by Yoon et al. (1996), with the exception that RNase T1 was used in combination with RNase A to minimize the contamination of RNA. The 16S rRNA gene was amplified by PCR using two universal primers, 5'-GAGTTTGATCCTGGCTCAG3' (positions 9-27 in Escherichia coli 16S rRNA numbering) and 5'-AGAAAGGAGGTGATCCAGCC-3' (positions 1542-1525 in E. coli 16S rRNA numbering), as described previously (Yoon et al., 1998). Sequencing of the amplified $16 \mathrm{~S}$ rRNA gene and phylogenetic analysis were performed as described by Yoon et al. (2003). Isoprenoid quinones were analysed as described by Komagata \& Suzuki (1987)

Table 1. Differential phenotypic characteristics of Salinihabitans gen. nov. and the genera Roseivivax, Salipiger, Citreicella, Yangia and Citreimonas

Genera: 1, Salinihabitans gen. nov.; 2, Roseivivax (data from Suzuki et al., 1999); 3, Salipiger (Martínez-Cánovas et al., 2004); 4, Citreicella (Sorokin et al., 2005; Choi \& Cho, 2006); 5, Yangia (Dai et al., 2006); 6, Citreimonas (Choi \& Cho, 2006). +, Positive reaction; -, negative reaction; w, weakly positive reaction; ND, not determined or not described; v, variable reaction. All genera are aerobic and positive for catalase activity. All genera are negative for Gram-staining.

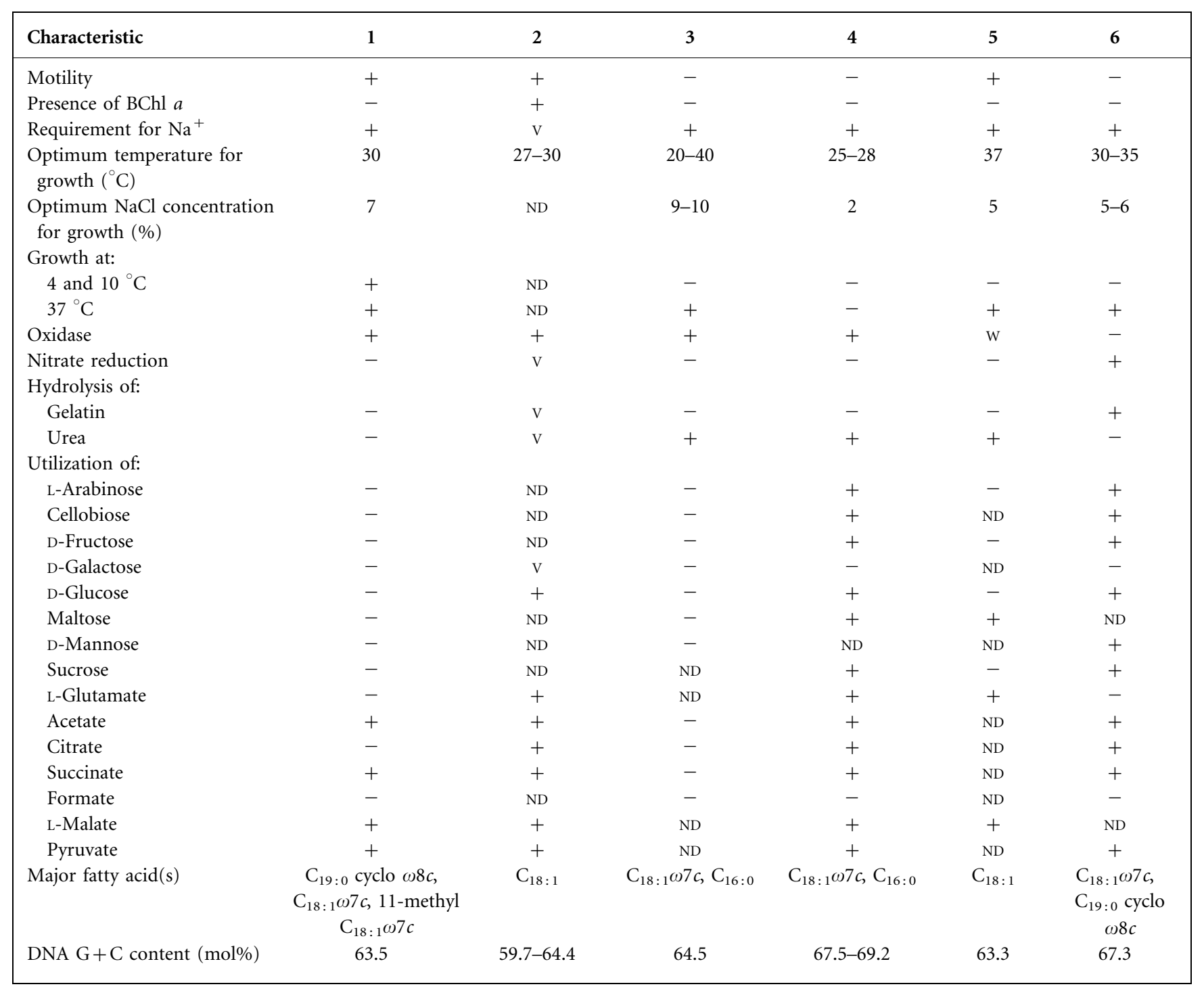


using reversed-phase HPLC. For cellular fatty acid analysis, cell mass of strain ISL- $46^{\mathrm{T}}$ was harvested from $5 \% \mathrm{NaCl}$ MA plates after cultivation for 7 days at $30{ }^{\circ} \mathrm{C}$. The fatty acids were extracted and fatty acid methyl esters were prepared according to the standard protocol of the MIDI/ Hewlett Packard Microbial Identification System (Sasser, 1990). The DNA G $+C$ content was determined by using the method of Tamaoka \& Komagata (1984) with the modification that DNA was hydrolysed using nuclease P1 (Sigma) and the resultant nucleotides were analysed by reversed-phase HPLC.

Morphological, cultural, physiological and biochemical characteristics of strain ISL- $46^{\mathrm{T}}$ are given in the genus and species descriptions (see below) or are shown in Table 1. The almost complete $16 \mathrm{~S}$ rRNA gene sequence of strain ISL- $46^{\mathrm{T}}$ determined in this study comprised $1421 \mathrm{nt}$, representing approximately $96 \%$ of the E. coli $16 \mathrm{~S}$ rRNA gene sequence. In the phylogenetic tree based on the neighbour-joining algorithm, strain ISL- $46^{\mathrm{T}}$ joined the clade comprising the genera Roseivivax (Suzuki et al., 1999), Salipiger (MartínezCánovas et al., 2004), Citreicella (Sorokin et al., 2005), Yangia (Dai et al., 2006) and Citreimonas (Choi \& Cho, 2006) (Fig. 1). This topology was also found in the tree constructed using the maximum-parsimony algorithm (Fig. 1). Strain ISL- $46^{\mathrm{T}}$ exhibited $16 \mathrm{~S}$ rRNA gene sequence similarity values of $94.6,94.1,95.0,94.2$ and $95.3 \%$ to the type strains of two Roseivivax species, Salipiger mucosus $\mathrm{A}^{\mathrm{T}}$, Citreicella thiooxidans CHLG $1^{\mathrm{T}}$, Yangia pacifica DX5 $-10^{\mathrm{T}}$ and Citreimonas salinaria CL-SP $20^{\mathrm{T}}$, respectively.

The predominant isoprenoid quinone detected in strain ISL- $46^{\mathrm{T}}$ was ubiquinone-10 (Q-10). The fatty acid profile of strain ISL- $46^{\mathrm{T}}$ was composed of the following (each constituting $>0.5 \%$ of total fatty acids): cyclo fatty acids $\mathrm{C}_{19: 0} \omega 8 c(46.2 \%)$ and $\mathrm{C}_{17: 0}(2.2 \%)$; unsaturated fatty acid $\mathrm{C}_{18: 1} \omega 7 c$ (18.4\%); 11-methyl $\mathrm{C}_{18: 1} \omega 7 c$ (15.1\%); straight-chain fatty acids $\mathrm{C}_{16: 0}(8.7 \%)$ and $\mathrm{C}_{17: 0}(0.5 \%)$; hydroxy fatty acid $\mathrm{C}_{12: 1} 3-\mathrm{OH}(3.2 \%)$; unknown fatty acid ECL 11.799 (2.2\%); and summed feature $3\left(\mathrm{C}_{16: 1} \omega 7 c\right.$ and/ or iso- $\left.\mathrm{C}_{15: 0} 2-\mathrm{OH}, 2.0 \%\right)$. The DNA $\mathrm{G}+\mathrm{C}$ content of strain ISL- $46^{\mathrm{T}}$ was $63.5 \mathrm{~mol} \%$.

The phylogenetic analyses based on 16S rRNA gene sequences showed that strain ISL $-46^{\mathrm{T}}$ did not fall within the radiation encompassed by a recognized genus but forms an independent evolutionary lineage within the Alphaproteobacteria (Fig. 1). The predominant ubiquinone type (Q-10) of strain ISL- $46^{\mathrm{T}}$ was identical to those of the phylogenetically related genera Roseivivax, Salipiger and Yangia (Suzuki et al., 1999; Martínez-Cánovas et al., 2004; Dai et al., 2006). However, the differences in major fatty acids, $\mathrm{C}_{19: 0}$ cyclo $\omega 8 c$ and 11-methyl $\mathrm{C}_{18: 1} \omega 7 c$, distinguished strain ISL-46 ${ }^{\mathrm{T}}$ from the genera Roseivivax, Salipiger, Citreicella, Yangia and Citreimonas, although these differences may partly result from different culture conditions and extraction procedures (Table 1). Strain ISL$46^{\mathrm{T}}$ could be also differentiated from the above-mentioned genera by differences in phenotypic properties, as listed in

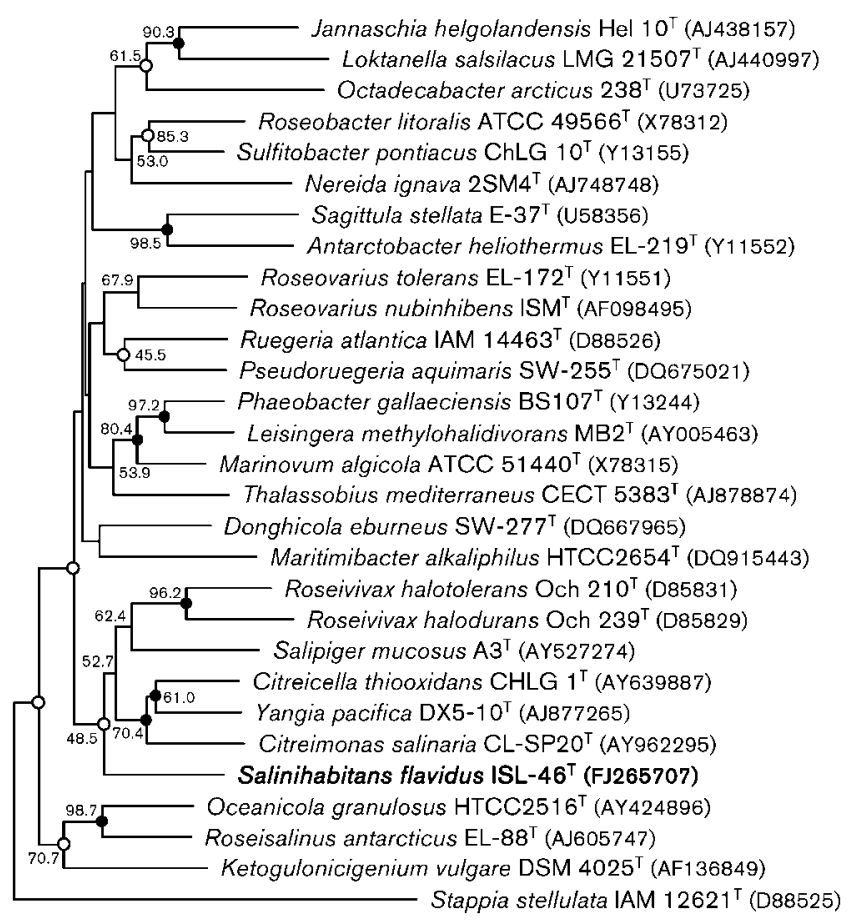

$\underline{0.01}$

Fig. 1. Neighbour-joining phylogenetic tree based on 16S rRNA gene sequences showing the positions of strain ISL-46 ${ }^{\top}$ (Salinihabitans flavidus gen. nov., sp. nov.) and some other related taxa. Bootstrap values (expressed as percentages of 1000 replications) of $>40 \%$ are shown at branch points. Filled circles indicate that the corresponding nodes were also recovered in the trees generated with the maximum-likelihood and maximumparsimony algorithms. Open circles indicate that the corresponding nodes were recovered in the tree generated with the maximumparsimony algorithm. Stappia stellulata IAM $12621^{\top}$ (GenBank accession number D88525) was used as an outgroup. Bar, 0.01 substitutions per nucleotide position.

Table 1. The phylogenetic data and differential chemotaxonomic and phenotypic properties suggest that strain ISL- $46^{\mathrm{T}}$ constitutes a new genus and novel species within the Alphaproteobacteria, for which the name Salinihabitans flavidus gen. nov., sp. nov. is proposed.

\section{Description of Salinihabitans gen. nov.}

Salinihabitans (Sa.li.ni.ha'bi.tans. L. fem. pl. n. salinae salterns, salt-works; L. part. adj. habitans inhabiting; N.L. part. adj. Salinihabitans inhabitant of salt-works).

Cells are Gram-negative and rod-shaped. The predominant ubiquinone is Q-10. The type species is Salinihabitans flavidus.

\section{Description of Salinihabitans flavidus sp. nov.}

Salinihabitans flavidus (fla'vi.dus. L. masc. adj. flavidus pale yellow). 
Exhibits the following properties in addition to those given in the genus description. Cells are $0.3-0.6 \times 0.8-4.5 \mu \mathrm{m}$ and motile by means of a single polar flagellum. Colonies on $5 \% \mathrm{NaCl} \mathrm{MA}$ are circular, convex, smooth, glistening, pale-yellow in colour and $0.5-0.8 \mathrm{~mm}$ in diameter after incubation for 7 days at $30{ }^{\circ} \mathrm{C}$. Growth occurs at 4 and $40{ }^{\circ} \mathrm{C}$, but not at $45^{\circ} \mathrm{C}$. Optimal $\mathrm{pH}$ for growth is between 7.0 and 8.0; growth occurs at $\mathrm{pH}$ 6.0, but not at $\mathrm{pH} 5.5$. Growth occurs in the presence of $17 \%(\mathrm{w} / \mathrm{v}) \mathrm{NaCl}$, but not in the absence of $\mathrm{NaCl}$ or in the presence of more than $18 \%$ (w/v) NaCl. Growth does not occur under anaerobic conditions. Hypoxanthine, xanthine and L-tyrosine are hydrolysed, but aesculin, casein, starch and Tweens 20, 40 and 60 are not. $\mathrm{H}_{2} \mathrm{~S}$ is not produced. Trehalose, D-xylose, benzoate and salicin are not utilized as sole carbon and energy sources. Susceptible to ampicillin, carbenicillin, cephalothin, chloramphenicol, gentamicin, kanamycin, neomycin, novobiocin, oleandomycin, penicillin $G$ and streptomycin, but not to lincomycin, polymyxin B or tetracycline. In assays with the API ZYM system, alkaline phosphatase, esterase (C4), esterase lipase (C8) and leucine arylamidase are present, but lipase (C14), valine arylamidase, cystine arylamidase, trypsin, $\alpha$-chymotrypsin, acid phosphatase, naphthol-AS-BI-phosphohydrolase, $\alpha$-galactosidase, $\beta$-galactosidase, $\beta$-glucuronidase, $\alpha$-glucosidase, $\beta$-glucosidase, $N$-acetyl- $\beta$-glucosaminidase, $\alpha$-mannosidase and $\alpha$-fucosidase are absent. Major fatty acids $(>10 \%$ of total fatty acids) are $\mathrm{C}_{19: 0}$ cyclo $\omega 8 c, \mathrm{C}_{18: 1} \omega 7 c$ and 11methyl $\mathrm{C}_{18: 1} \omega 7 c$. The DNA G+C content of the type strain is $63.5 \mathrm{~mol} \%$ (determined by HPLC). Other phenotypic characteristics are given in Table 1.

The type strain, ISL $-46^{\mathrm{T}} \quad\left(=\mathrm{KCTC} \quad 22485^{\mathrm{T}}=\mathrm{CCUG}\right.$ $56758^{\mathrm{T}}$ ), was isolated from a marine solar saltern of the Yellow Sea, Korea.

\section{Acknowledgements}

This work was supported by the 21C Frontier program of Microbial Genomics and Applications (grant MG05-0401-2-0) from the Ministry of Education, Science and Technology (MEST) of the Republic of Korea.

\section{References}

Baumann, P. \& Baumann, L. (1981). The marine Gram-negative eubacteria: genera Photobacterium, Beneckea, Alteromonas,
Pseudomonas, and Alcaligenes. In The Prokaryotes, pp. 1302-1331. Edited by M. P. Starr, H. Stolp, H. G. Trüper, A. Balows \& H. G. Schlegel. Berlin: Springer-Verlag.

Bruns, A., Rohde, M. \& Berthe-Corti, L. (2001). Muricauda ruestringensis gen. nov., sp. nov., a facultatively anaerobic, appendaged bacterium from German North Sea intertidal sediment. Int $J$ Syst Evol Microbiol 51, 1997-2006.

Choi, D. H. \& Cho, B. C. (2006). Citreimonas salinaria gen. nov., sp. nov., a member of the Roseobacter clade isolated from a solar saltern. Int J Syst Evol Microbiol 56, 2799-2803.

Cowan, S. T. \& Steel, K. J. (1965). Manual for the Identification of Medical Bacteria. London: Cambridge University Press.

Dai, X., Wang, B.-J., Yang, Q.-X., Jiao, N.-Z. \& Liu, S.-J. (2006). Yangia pacifica gen. nov., sp. nov., a novel member of the Roseobacter clade from coastal sediment of the East China Sea. Int J Syst Evol Microbiol 56, 529-533.

Komagata, K. \& Suzuki, K. (1987). Lipids and cell-wall analysis in bacterial systematics. Methods Microbiol 19, 161-207.

Lányí, B. (1987). Classical and rapid identification methods for medically important bacteria. Methods Microbiol 19, 1-67.

Martínez-Cánovas, M. J., Quesada, E., Martínez-Checa, F., del Moral, A. \& Béjar, V. (2004). Salipiger mucescens gen. nov., sp. nov., a moderately halophilic, exopolysaccharide-producing bacterium isolated from hypersaline soil, belonging to the $\alpha$ Proteobacteria. Int J Syst Evol Microbiol 54, 1735-1740.

Sasser, M. (1990). Identification of bacteria by gas chromatography of cellular fatty acids, MIDI Technical Note 101. Newark, DE: MIDI Inc.

Sorokin, D. Y., Tourova, T. P. \& Muyzer, G. (2005). Citreicella thiooxidans gen. nov., sp. nov., a novel lithoheterotrophic sulfuroxidizing bacterium from the Black Sea. Syst Appl Microbiol 28, 679-687.

Suzuki, T., Muroga, Y., Takahama, M. \& Nishimura, Y. (1999). Roseivivax halodurans gen. nov., sp. nov. and Roseivivax halotolerans sp. nov., aerobic bacteriochlorophyll-containing bacteria isolated from a saline lake. Int J Syst Bacteriol 49, 629-634.

Tamaoka, J. \& Komagata, K. (1984). Determination of DNA base composition by reversed-phase high-performance liquid chromatography. FEMS Microbiol Lett 25, 125-128.

Yoon, J.-H., Kim, H., Kim, S.-B., Kim, H.-J., Kim, W. Y., Lee, S. T., Goodfellow, M. \& Park, Y.-H. (1996). Identification of Saccharomonospora strains by the use of genomic DNA fragments and rRNA gene probes. Int J Syst Bacteriol 46, 502-505.

Yoon, J.-H., Lee, S. T. \& Park, Y.-H. (1998). Inter- and intraspecific phylogenetic analysis of the genus Nocardioides and related taxa based on 16S rRNA gene sequences. Int J Syst Bacteriol 48, 187-194.

Yoon, J.-H., Kang, K. H. \& Park, Y.-H. (2003). Psychrobacter jeotgali sp. nov., isolated from jeotgal, a traditional Korean fermented seafood. Int J Syst Evol Microbiol 53, 449-454. 